\title{
The Association between Total Body Fat and Serum Lipids Concentrations in College Students
}

\author{
Jun-Ho Lee
}

Department of Clinical Laboratory Science, Wonkwang Health Science University, Iksan, Korea

\section{대학생에서 혈액 지질 수준과 체지방과의 관련성}

이준호

원광보건대학교 임상병리과

\begin{abstract}
This study was conducted to investigate the relationship between body fat content and serum lipids in college students. A total of 61 (15 males and 46 females) students of W university in Iksan, between June 2015 and July 2015, were enrolled for analysis. The relationship of serum lipid with $\mathrm{BMI}$, and body fat percent measured by impedance fat meter (InBody 520) was analyzed. The study population was divided into three groups according to the InBody 520's guideline. Group I accounted for $26.7 \%$ of men and $10.9 \%$ of women. Weight and BMI were significantly different among the three groups in men and women $(p<0.05)$; whereas height was not. In men, serum total cholesterol, triglyceride, low density lipoprotein cholesterol, and hemoglobin were significantly different between the three groups $(p<0.05)$. Conversely, in women, serum total cholesterol, low density lipoprotein cholesterol, and alanine transferase were significantly different between the three groups $(p<0.05)$. However, there were no differences in other variables between the three groups. BMI was significantly different among three groups in both men and women $(p<0.05)$. In men and women, body fat percent was correlated with BMI, weight, total cholesterol, and low density lipoprotein cholesterol. Multiple regression analysis on total cholesterol indicates that body fat percent, BMI, and hemoglobin were not significantly independent variables in men and women. This study showed that body fat percent was significantly associated with other obesity markers and serum lipids.
\end{abstract}

Key words: Body fat, Lipids, Cholesterol

This is an Open Access article distributed under the terms of the Creative Commons Attribution Non-Commercial License (http://creativecommons.org/licenses/by-nc/4.0) which permits unrestricted non-commercial use, distribution, and reproduction in any medium, provided the original work is properly cited.

Copyright @ 2017 The Korean Society for Clinical Laboratory Science. All rights reserved.
Corresponding author: Jun-Ho Lee

Department of Clinical Laboratory Science, Wonkwang Helath Science University, 514 Iksan Daero, Iksan 54538, Korea

Tel: 82-63-840-1213

Fax: 82-63-840-1219

E-mail: onepot@wu.ac.kr

Received: July 28, 2017

Revised $1^{\text {st: }}$ : August 19, 2017

Revised 2 ${ }^{\text {nd }}$ : August 22, 2017

Revised $3^{\text {rd: }}$ : August 23, 2017

Revised $4^{\text {th }}$ : August 24, 2017

Revised 5 $5^{\text {th }}$ : August 24, 2017

Accepted: August 24, 2017

\section{서 론}

최근 전 세계적으로 비만 인구가 급격히 증가하면서 보건학 적으로 중요한 문제로 대두되고 있다[1]. 우리나라도 경제발전 을 통하여 물질적인 풍요와 생활수준은 향상되었지만 행동양식 의 변화와 식생활의 서구화로 인해 비만이 증가하는 추세에 있
다[2]. 비만은 당뇨병, 고혈압, 이상지질혈증, 관상동맥질환 등 혈청 지질의 상승을 통하여 동맥경화성 질환을 동반하는 대사 증후군의 유병률을 증가시키며 말초혈관의 저항성 증가로 인하 여 혈압을 상승시키고[3-7], 관절염, 통풍, 담석증, 호흡기 계통 의 이상, 유방암 등의 빈도도 증가한다[8-9]. 따라서 비만과 과 체중으로 인한 질병에 대한 부담이 높은 것으로 추정되어 예방 
관리의 중요성과 국민적 관심이 증가하게 되었다[10].

이상지질혈증이 있는 사람은 체질량지수(Body Mass Index, $\mathrm{BMI}$ )가 크고 체질량지수는 중성지방(triglyceride, TG), 저밀 도지단백콜레스테롤(low density lipoprotein-cholesterol, $\mathrm{LDL}-\mathrm{C}$ ) 등과는 양의 상관관계가 있고 고밀도지단백콜레스테 롤(high density lipoprotein-cholesterol, HDL-C)과는 음의 상관관계가 있다는 다수의 연구가 있다[11-13]. 또한 BMI가 커 질수록 혈청 TG와 총콜레스테롤(total-cholesterol)이 유의하 게 증가되고, 혈압과 혈청 지질값도 유의한 관련성이 보고되고 있다[14-16]. 따라서 비만과 혈청 지질 수준, 고혈압은 서로 밀 접한 상관관계가 있음을 알 수 있다. 체지방률은 BMI와는 별도 로 체중당 체지방량이 차지하는 비율로 알 수 있는 객관적인 비 만 측정 지수로 신체 운동 수행 능력과 개인의 건강도를 알 수 있 는 중요한 지표로 사용되고 있다[17]. 최근까지 국내에 많이 보 급되고 있는 InBody는 생체전기저항분석법(Bioimpedance analysis)의 원리를 이용하여 체지방률을 측정할 수 있는 장비 로서 체지방률뿐만 아니라 체지방량, 근육량 등 많은 신체정보 를 얻을 수 있어 신체의 구성성분을 분석하는데 많이 이용되고 있다[18]. 그러나 최근에 생체전기저항분석법을 이용하여 전체 적인 지방량으로 비만의 정도를 평가하여 혈액 지질 수준과의 관련성을 조사한 연구는 미흡한 실정이다. 따라서 저자는 20 대 대학생을 대상으로 체지방분석기로 이용하여 구한 체지방 비율 을 구하여 비만의 정도를 평가하고 체지방의 비율과 혈액 지질 수준과의 관련성을 알아보고자 하였다.

\section{재료 및 방법}

\section{1. 재료}

본 연구는 2015년 6월부터 7월까지 W대학교 학생을 대상으 로 체지방 측정, 신체계측, 혈액검사 등을 실시하였다. 연구대상 자는 총 61 명(남 15 명, 여 45 명)이 연구에 참여하였다. 본 연구 에 참여한 모든 대상자에게 연구의 목적을 설명하고 연구방법 및 참여기간, 부작용 및 위험요소, 개인정보와 비밀보장에 대한 내용을 공지하고 각각의 서면 사전 동의를 얻어 연구를 수행하 였다.

\section{2. 자료수집 및 측정}

조사 대상자의 체지방 측정은 Impedance fat meter로 많이 이용되는 InBody 520 (Biospace, Cheonan, Korea)을 사용하 였으며, 신체계측은 반바지와 반팔 상의의 가벼운 옷차림 상태 에서 신체자동계측기로 신장과 체중을 0.1 단위까지 측정하였
다. 비만도를 측정하기 위하여 현재 가장 일반적으로 이용되는 $\mathrm{BMI}$ 를 이용하였으며 신장의 제곱으로 체중을 나누어 계산하였 다. 대상자는 8시간 이상 공복 상태에서 검사를 실시하였으며, 혈색소검사는 LC-660 자동혈구계산기(HORIBA, Kyoto, Japan) 을 이용하여 실시하였다. 총콜레스테롤, TG, HDL-C, 간기능검 사(liver function test, LFT), 신장기능검사(renal function test, RFT)를 포함한 생화학 검사는 Olympus AU400 analyser (Olympus, Tokyo, Japan)를 이용하여 분석하였다. 비만은 BMI $25 \mathrm{~kg} / \mathrm{m}^{2}$ 이상, 고지혈증은 총콜레스테롤 $240 \mathrm{mg} / \mathrm{dL}$ 이 상, TG $150 \mathrm{mg} / \mathrm{dL}$ 이상인 경우 증가군으로 정의하였고, $\mathrm{HDL}-\mathrm{C}$ 는 $40 \mathrm{mg} / \mathrm{dL}$ 미만인 경우 감소군으로 분류하였다. 체지 방 비율을 기준으로 대상자를 3 군으로 분류하였는데 본 연구에 서 이용된 InBody 520 제조사에서 제공되는 Index와 선행연구 의 분류를 참고하여, 남자는 체지방 비율이 $25 \%$ 이상을 과체중, $20 \%$ 이상에서 $25 \%$ 미만을 경계영역, $15 \%$ 이상에서 $20 \%$ 미만 을 정상군, $15 \%$ 미만을 저체중으로 분류하였고, 여자는 체지방 비율에 따라 $30 \%$ 이상을 과체중, $25 \%$ 이상에서 $30 \%$ 미만을 경 계영역, $20 \%$ 이상에서 $25 \%$ 미만을 정상, $20 \%$ 미만을 저체중으 로 분류하였다[19-20]. 본 연구에서는 남녀 각각 과체중과 경계 영역을 1 군, 정상인을 제 2 군, 저체중을 3 군으로 분류하였다. 모 든 검체는 공복 상태에서 채취하였으며 검사는 엄격한 정도관 리와 함께 분석이 이루어졌다.

\section{3. 통계분석}

체지방 비율을 이용하여 대상자를 3 군으로 나누어 분석하였 고, 모든 결과 값은 ‘평균표준편차’ 로 제시하였다. 모든 통계 분석은 PASW Statistics version 18.0 (SPSS, Chicago, USA) 프 로그램을 이용하여 평균, 표준편차, 독립표본 $\mathrm{t}$ 검정과 일원분산 분석, 상관관계분석, 다중회귀분석을 실시하였다.

\section{결 과}

대상자는 61 명 중 남자 15 명 $(24.8 \%)$, 여자 46 명 $(75.5 \%)$ 이었 고 평균연령은 남자 22.6세, 여자 20.4세였다. 체지방 비율에 따 른 대상자의 분포는 1 군(남자: 체지방량 $\geq 20$, 여자: 체지방량 $\geq 25$ ) 9명(14.8\%), 2군(남자: $20>$ 체지방량 $\geq 15$, 여자: $25>$ 체지방량 $\geq 20$ ) 13명(21.3\%), 3군(남자: $15>$ 체지방량, 여자: 20 >체지방량) 39명(63.9\%)으로 3군이 가장 많았다(Table 1).

조사 대상자들 중 남자의 체지방률 별 신장은 1 군 $172.2 \mathrm{~cm}$, 2 군 $171.5 \mathrm{~cm}, 3$ 군 $171.3 \mathrm{~cm}$ 로 세 군간의 유의한 차이가 없었 으나, 체중은 각각 $80.3 \mathrm{~kg}, 71.8 \mathrm{~kg}, 58.8 \mathrm{~kg}$ 으로 세 군간의 유 
Table 1. The distribution of subjects by groups classified on body fat percent

\begin{tabular}{lcccc}
\hline Sex (Age) & Group I (\%) & Group II (\%) & Group III (\%) & Total (\%) \\
\hline Male (22.6) & $4(26.7)$ & $5(33.3)$ & $6(40.0)$ & $15(24.8)$ \\
Female (20.4) & $5(10.9)$ & $8(17.4)$ & $33(71.7)$ & $46(75.5)$ \\
Total & $9(14.8)$ & $13(21.3)$ & $39(63.9)$ & $61(100)$ \\
\hline
\end{tabular}

Table 2. Mean values of variable by groups classified on body fat percent in male

\begin{tabular}{|c|c|c|c|c|}
\hline Variable & Group I & Group II & Group III & $p$-value \\
\hline Height $(\mathrm{cm})$ & $172.2 \pm 9.2$ & $171.5 \pm 5.8$ & $171.3 \pm 7.3$ & NS \\
\hline Weight $(\mathrm{kg})^{\star}$ & $80.3 \pm 5.6$ & $71.8 \pm 6.7$ & $58.8 \pm 4.8$ & $<0.05$ \\
\hline BMI $\left(\mathrm{kg} / \mathrm{m}^{2}\right)^{\star}$ & $29.7 \pm 4.6$ & $23.3 \pm 2.2$ & $20.2 \pm 2.1$ & $<0.05$ \\
\hline $\mathrm{TCHO}(\mathrm{mg} / \mathrm{dL})^{\star}$ & $205.7 \pm 47.5$ & $176.4 \pm 28.2$ & $168.8 \pm 18.6$ & $<0.05$ \\
\hline $\mathrm{TG}(\mathrm{mg} / \mathrm{dL})^{\star}$ & $140.5 \pm 78.7$ & $128.4 \pm 72.3$ & $110.5 \pm 63.7$ & $<0.05$ \\
\hline HDL-Chol (mg/dL) & $56.0 \pm 7.7$ & $52.5 \pm 8.4$ & $56.4 \pm 11.1$ & NS \\
\hline LDL-Chol (mg/dL)* & $115.2 \pm 31.6$ & $102.3 \pm 30.5$ & $96.2 \pm 35.7$ & $<0.05$ \\
\hline $\mathrm{Hb}(\mathrm{g} / \mathrm{dL})^{\star}$ & $16.1 \pm 0.7$ & $14.7 \pm 0.6$ & $14.2 \pm 1.2$ & $<0.05$ \\
\hline ALT (IU) & $24.5 \pm 17.2$ & $21.5 \pm 18.0$ & $10.1 \pm 3.9$ & NS \\
\hline $\mathrm{TP}(\mathrm{g} / \mathrm{dL})$ & $7.7 \pm 0.8$ & $7.4 \pm 0.3$ & $7.5 \pm 0.4$ & NS \\
\hline
\end{tabular}

BMI, body mass index; TCHO, total cholesterol; TG, triglycerides; HDL-Chol, high density lipoprotein cholesterol; LDL-Chol, low density lipoprotein cholesterol; Hb, blood hemoglobin; ALT, alanine transferase; TP, total protein; NS, not significant.

*significant.

Table 3. Mean values of variable by groups classified on body fat percent in female

\begin{tabular}{lcccc}
\hline \multicolumn{1}{c}{ Variable } & Group I & Group II & Group III & $p$-value \\
\hline Height $(\mathrm{cm})$ & $157.5 \pm 6.2$ & $159.5 \pm 7.6$ & $160.1 \pm 6.3$ & $\mathrm{NS}$ \\
Weight $(\mathrm{kg})^{*}$ & $81.1 \pm 10.5$ & $61.1 \pm 3.7$ & $50.1 \pm 6.3$ & $<0.05$ \\
BMI $\left(\mathrm{kg} / \mathrm{m}^{2}\right)^{*}$ & $29.1 \pm 4.3$ & $24.9 \pm 3.4$ & $21.0 \pm 2.8$ & $<0.05$ \\
TCHO $(\mathrm{mg} / \mathrm{dL})^{*}$ & $185.2 \pm 22.3$ & $176.8 \pm 33.1$ & $172.5 \pm 29.5$ & $<0.05$ \\
TG (mg/dL) & $137.6 \pm 72.4$ & $84.8 \pm 37.6$ & $78.4 \pm 26.6$ & $\mathrm{NS}$ \\
HDL-Chol $(\mathrm{mg} / \mathrm{dL})$ & $51.4 \pm 15.9$ & $65.1 \pm 18.0$ & $61.9 \pm 13.4$ & $\mathrm{NS}$ \\
LDL-Chol (mg/dL)* & $119.4 \pm 34.6$ & $110.4 \pm 23.7$ & $98.6 \pm 33.6$ & $<0.05$ \\
Hb (g/dL) & $12.9 \pm 0.4$ & $13.0 \pm 0.5$ & $13.0 \pm 0.9$ & $\mathrm{NS}$ \\
ALT (IU)* & $27.0 \pm 26.6$ & $8.2 \pm 3.3$ & $7.0 \pm 4.4$ & $<0.05$ \\
TP $(\mathrm{g} / \mathrm{dL})$ & $7.5 \pm 0.4$ & $7.3 \pm 0.6$ & $7.4 \pm 0.7$ & $\mathrm{NS}$ \\
\hline
\end{tabular}

See Table 2.

의한 차이가 있었다 $(p<0.05)$. BMI는 1 군 $29.7 \mathrm{~kg} / \mathrm{m}^{2}, 2$ 군 $23.3 \mathrm{~kg} / \mathrm{m}^{2}, 3$ 군 $20.2 \mathrm{~kg} / \mathrm{m}$ 로 세 군간에는 유의한 차이가 있었 다 $(p<0.05)$. 혈청 지질수준은 총콜레스테롤이 1 군 205.7 $\mathrm{mg} / \mathrm{dL}, 2$ 군 $176.4 \mathrm{mg} / \mathrm{dL}, 3$ 군 $168.8 \mathrm{mg} / \mathrm{dL}$ 이었고, TG는 1군 $140.5 \mathrm{mg} / \mathrm{dL}, 2$ 군 $128.4 \mathrm{mg} / \mathrm{dL}, 3$ 군 $110.5 \mathrm{mg} / \mathrm{dL}$ 였으며, $\mathrm{HDL}-\mathrm{C}$ 은 1 군 $56.0 \mathrm{mg} / \mathrm{dL}, 2$ 군 $52.4 \mathrm{mg} / \mathrm{dL}, 3$ 군 $56.4 \mathrm{mg} / \mathrm{dL}$ 을 보였고, LDL-C은 1군 $115.2 \mathrm{mg} / \mathrm{dL}, 2$ 군 $102.3 \mathrm{mg} / \mathrm{dL}, 3$ 군 $96.2 \mathrm{mg} / \mathrm{dL}$ 을 보였다. 또한 적혈구 헤모글로빈은 1 군 16.1 $\mathrm{g} / \mathrm{dL}, 2$ 군 $14.71 \mathrm{~g} / \mathrm{dL}, 3$ 군 $14.21 \mathrm{~g} / \mathrm{dL}$ 를 보였으며, 총콜레스 테롤, TG, HDL-C, LDL-C, 헤모글로빈 모두는 세 군간에 유의 한 차이가 있었다 $(p<0.05)$ (Table 2).

조사대상자들 중 여자의 체지방률에서 신장은 1 군 157.5 $\mathrm{cm}, 2$ 군 $159.5 \mathrm{~cm}, 3$ 군 $160.1 \mathrm{~cm}$ 로 세 군간에 유의한 차이가 없었으나 체중은 각각 $81.1 \mathrm{~kg}, 61.1 \mathrm{~kg}, 50.1 \mathrm{~kg}$ 으로 세 군간에 는 유의한 차이가 있었다 $(p<0.05)$. BMI는 1 군 $29.1 \mathrm{~kg} / \mathrm{m}^{2}, 2$ 군 $24.9 \mathrm{~kg} / \mathrm{m}^{2}, 3$ 군 $21.0 \mathrm{~kg} / \mathrm{m}^{2}$ 으로 역시 세 군간에는 유의한 차이가 있었다 $(p<0.05)$. 혈액 지질수준은 총콜레스테롤이 1군 $185.2 \mathrm{mg} / \mathrm{dL}, 2$ 군 $176.8 \mathrm{mg} / \mathrm{dL}, 3$ 군 $172.5 \mathrm{mg} / \mathrm{dL}$ 이었고, TG 는 1 군 $137.6 \mathrm{mg} / \mathrm{dL}, 2$ 군 $84.8 \mathrm{mg} / \mathrm{dL}, 3$ 군 $78.4 \mathrm{mg} / \mathrm{dL}$ 였으며, $\mathrm{HDL}-\mathrm{C}$ 은 1군 $51.4 \mathrm{mg} / \mathrm{dL}, 2$ 군 $65.1 \mathrm{mg} / \mathrm{dL}, 3$ 군 $61.9 \mathrm{mg} / \mathrm{dL}$ 을 보였고 LDL-C은 1 군 $119.4 \mathrm{mg} / \mathrm{dL}, 2$ 군 $110.4 \mathrm{mg} / \mathrm{dL}, 3$ 군 $98.6 \mathrm{mg} / \mathrm{dL}$ 을 보였다. 또한 적혈구 헤모글로빈은 1 군 12.9 $\mathrm{g} / \mathrm{dL}, 2$ 군 $13.0 \mathrm{~g} / \mathrm{dL}, 3$ 군 $13.0 \mathrm{~g} / \mathrm{dL}$ 를 보였으며 총콜레스테롤, LDL-C, ALT는 세 군간에 유의한 차이를 보였다 $(p<0.05)$ 
Table 4. Multiple regression anaysis of total cholesterol by confounding variables in male and female

\begin{tabular}{cccc}
\hline sex & Independent variables & $r$ & $p$ \\
\hline Male* & body fat (\%) & 0.24 & NS \\
& BMI $\left(\mathrm{kg} / \mathrm{m}^{2}\right)$ & 0.17 & $\mathrm{NS}$ \\
Female $^{\dagger}$ & $\mathrm{Hb}(\mathrm{g} / \mathrm{dL})$ & 0.39 & $<0.05$ \\
& body fat $(\%)$ & 0.21 & $\mathrm{NS}$ \\
& $\mathrm{BMI}\left(\mathrm{kg} / \mathrm{m}^{2}\right)$ & 0.15 & $\mathrm{NS}$ \\
& $\mathrm{Hb}(\mathrm{g} / \mathrm{dL})$ & 0.11 & $\mathrm{NS}$ \\
\hline
\end{tabular}

${ }^{*} R^{2}=0.63,{ }^{\dagger} R^{2}=0.15$, See Table 2 .

(Table 3).

남녀 모두 각 변수들과의 상관관계를 분석한 결과 체지방 비 율은 $\mathrm{BMI}$ 와 높은 상관관계를 가지고 있었고, 체중, 총콜레스테 롤, 중성지방, LDL-C과 유의한 상관관계를 보였다. 또한 심혈 관계 질환의 위험인자인 총콜레스테롤에 영향을 미치는 변수를 파악하기 위해 총콜레스테롤을 종속변수로 하고 BMI, 체지방 률, 에모글로빈을 독립변수로 하여 다중회귀분석을 실시하였 으나 남녀 모두 유의한 차이를 보이지 않았다(Table 4).

\section{고 찰}

비만은 당뇨병, 고혈압, 고지혈증 및 관상동맥질환 등 대사질 환과 밀접한 관련이 있으며, 순환기계 질환의 중요한 위험인자 로 알려져 있다. 미국의 역학조사에 의하면 1976년부터 1980 년대 초에는 비만율이 $25 \%$ 이었으며 1988년 이후 1990 년대 초 에는 그 비율이 $33 \%$ 로 증가하고 1999 년도 이후에는 $61 \%$ 로 빠 르게 증가되고 있다[21]. 또한 몇 선행연구에서 비만의 정도와 관상동맥질환의 관련성이 보고되고 있으며 중요한 위험인자로 알려져 있는 고혈압, 고콜레스테롤혈증, 낮은 $\mathrm{HDL}-\mathrm{C}$, 높은 LDL-C, 당뇨병과 관련이 있는 것으로 보고되고 있다[21,22]. 또한 전통적으로 순환계질환의 위험인자로서 특히 비만 어린이 에서 연관성이 높게 보고되어 소아비만은 향후 심혈관계 질환 의 중요한 원인이 되고 있다[23].

우리나라에서는 1970년대 이후 경제발전을 통하여 물질적 인 풍요와 생활수준은 향상되었지만 노인 인구의 증가로 인한 만성퇴행성질환이 증가되고 있어 중요한 보건문제로 대두되고 있다[2]. 그 중에서 비만과 고혈압은 대표적인 대사성질환으로 둘 사이에는 관련성이 매우 높다. 최근 우리나라에서도 전체 인 구 중에서 비만 인구가 차지하는 비율이 점차 증가하고 있는 추 세여서 비만은 개인적인 문제일 뿐만 아니라 국가적인 보건문 제로 대두되고 있는 실정이다[10].

비만의 병리학적 정의는 지방세포의 비대나 수적인 증가로
인하여 지방조직의 축적이 표준체중의 $20 \%$ 를 초과하는 것을 말한다. 비만의 정확한 평가와 대책을 수립하기 위해서는 체지 방량을 정확하게 측정하는 것이 매우 중요하다. 체지방을 측정 하는 방법에는 체밀도법, 체내 총수분량에서 체내지방량 환산 법, 방사성동위원소를 이용하여 검사하는 방법, $\mathrm{X}$-선을 이용하 여 피하지방의 두께를 측정하는 방법 등이 있으며, 비만도는 신 장과 체중을 이용하여 표시하는데 BMI, 체중/신장법, Ponderal 지수 등이 있다[24]. 그러나 임상에서는 앞에서 언급한 직접적 인 체지방 측정방법은 어렵기 때문에 BMI, 피부두께 측정 및 표 준체중표 같은 간접적으로 체지방을 측정하고 있다. 본 연구에 서는 부담이 적고 간편하며 적은 비용으로 측정할 수 있는 생체 전기저항분석법을 이용하여 전체적인 체지방량 비율을 구하고 신체를 계측하여 $\mathrm{BMI}$ 를 계산하고 혈액 지질 농도를 이용하여 동맥경화 지수를 구하여여 체지방률과 비만도 지수 및 혈청지 질 수준과의 관련성을 연구하였다.

본 연구에서는 대상자들을 체지방률에 따라 1 군, 2 군, 3 군으 로 나누었는데 2군과 3 군의 비율이 많이 나타났고 체지방 비율 이 $20 \%$ 이상인 1 군 남자의 비율은 $26.7 \%$ 이고 체지방비율이 $25 \%$ 이상인 1 군 여자의 비율은 $10.9 \%$ 의 결과로 선행연구 $[17,25]$ 와 비슷한 결과를 보였지만 3 군의 비율이 비정상적으로 높았다. 이는 대학생을 대상으로 한 Jang 등의 연구와 비슷한 결 과를 보였다[25]. 학교보건에 있어서 대학생들은 보건관리의 사각지대에 놓여있다고 할 수 있다. 불규칙한 생활과음주, 흡연 등에 자유롭게 노출됨으로써 생리적 기능과 정서적 불안정, 스 트레스를 받는 등 개인의 신체적·정서적 건강에 부정적인 영향 을 주는 시기인데도 불구하고 보건관리의 주체가 없는 실정이 다[25-27]. 이런 이유가 대학생만을 대상으로 한 연구가 선행연 구와 많은 차이를 보이는 이유로 생각된다.

고지혈증은 혈액 총콜레스테롤과 중성지방이 증가한 상태로 관상동맥질환의 중요한 위험인자로 고혈압이 동반될 때 그 위 험이 더욱 증가한다[22]. 지질관련 항목 중 심혈관계질환의 직 접적인 위험인자인 총콜레스테롤이 남녀 모두에서 유의하게 높 은 결과를 보여 Jang 등[25]과 Kim 등[17]의 선행연구와 일치 하는 결과를 보였다. 또한 비만도를 나타내는 체지방률과 혈청 지질 수준도 유의한 상관관계를 나타내어 BMI가 증가할수록 혈 청 총콜레스테롤 농도도 함께 증가한다고 보고한 Kim 등[17]의 연구결과와 차이를 보이지 않았다. 일반적으로 콜레스테롤은 나이가 가장 큰 변수로 알려져 있으나[28], 본 연구는 20대를 대 상으로 하여 나이는 변수로 사용하지 못했다. TG 농도와 총콜레 스테롤의 농도는 같은 경향을 보여서 BMI가 증가할수록 같이 증가한다는 연구가 있는데[9,29], 본 연구에서도 남녀 모두 
$\mathrm{BMI}$ 가 증가함에 따라 TG도 함께 증가하여 유의한 상관관계를 보였다. HDL-C은 남녀 모두에서 BMI와 상관관계가 없었고 체 지방군과도 유의성을 보이지 않았다. Lubkowska 등[30]의 지 질단백대사 연구에서 아디포넥틴(adiponectin)과 렙틴 (leptin)이 체지방 분포 및 지질과의 관련성 연구에서는 지방대 사를 포함하여 $\mathrm{HDL}-\mathrm{C}$ 와 양의 상관관계가 있다는 결과와는 차 이가 있다. 아마도 측정방법의 차이와 조사대상자의 특성이 다 르기 때문으로 생각된다.

총콜레스테롤 농도를 종속변수로 한 다중회귀분석에서 남자 와 여자 모두에서 체지방 비율, BMI가 총콜레스테롤의 농도에 영향을 미치는 변수로 작용하지 못했는데 선행연구에서 체지방 률, 나이, BMI가 영향을 미치는 변수를 보인다는 연구와차이를 보였다[17,25,31]. 이는 조사대상자의 수가 적고 대학생을 대 상으로 하여 연령대가 한정되었기 때문으로 보여진다.

본 연구에서는 생체전기저항분석법을 이용하여 간단하고 빠 르게 측정한 결과치를 이용하여 구한 체지방률과 기존의 대부 분의 연구에서 사용된 비만도 지수를 이용하였는데 체지방 비 율이 BMI와 유사하게 혈청 지질 수준과 유의한 상관관계를 나 타내어 계속 비만을 평가하는 도구로 사용하는데 문제가 없을 것으로 생각된다. 그러나 체지방비율이 혈액 콜레스테롤의 농 도에 영향을 미치는 유의한 상관관계가 있는 요인에 대한 증거 는 보이지 않았다.

본 연구는 최근 진료를 위한 도구뿐만 아니라 헬스장 등 여러 곳에서 사용되는 체지방측정기의 체지방률과 혈청 지질 사이의 관계를 알아보았지만 몇 가지 제한점이 있다. 첫째 혈압 등 다양 한 심혈관 인자를 검사하지 못했고, 두 번째 대상자의 수와 연령 에 한계가 있었고, 세 번째 체지방률과 심혈관계 질환의 원인이 되는 총콜레스테롤과의 인과관계를 밝히지 못하는 단면연구의 제한점이 있다. 앞으로 본 연구에 포함되지 않은 다른 요인들도 독립변수로 고려한 후 체지방 비율이 성인의 지질수준에 미치 는 영향에 대한 추가연구가 필요할 것으로 생각된다.

\section{요 약}

본 연구는 대학생을 대상으로 체지방률과 혈청 지질 수준의 관련성을 알아보고자 시행하였다. 2015년 6월부터 8월까지 W 대학에 재학중인 남자 15 명 여자 46 명을 대상으로 신체계측, 체 지방률, 혈액 검사 등을 실시하였다. 체지방률을 InBody 제조 사 guideline에 따라 세 그룹으로 나누었는데 1군 남자의 비율 은 $26.7 \%$, 여자의 비율은 $10.9 \%$ 였다. 세 그룹에서 체중과 체질 량지수는 남녀 모두 유의한 차이를 보였으나 $(p<0.05)$ 신장은
유의한 차이가 없었다. 남자는 세 그룹에서 총콜레스테롤, 중성 지방, 저밀도지단백콜레스테롤, 헤모글로빈이 유의한 차이를 보였고 $(p<0.05)$, 여자에서는 총콜레스테롤, 저밀도지단백콜 레스테롤, 알라닌전이효소가 유의한 차이를 보였다 $(p<0.05)$. 남녀 모두 각 변수들과의 상관관계를 분석한 결과 체지방 비율 은 BMI와 높은 상관관계를 가지고 있었고, 체중, 총콜레스테롤, $\mathrm{LDL}-\mathrm{C}$ 와 유의한 상관관계를 보였다 $(p<0.05)$. 또한 심혈관계 질환의 위험인자인 총콜레스테롤에 영향을 미치는 변수를 파악 하기 위해 총콜레스테롤을 종속변수로 하고 BMI, 체지방률, 헤 모글로빈을 독립변수로 하여 다중회귀분석을 실시하였으나 남 녀 모두 유의한 차이를 보이지 않았다. 본 연구는 체지방률과 혈 청 지질 수준과 유의한 관계가 있음을 보여준다.

Acknowledgements: 본 연구는 2015학년도 원광보건대학교 교내연구비에 의해 수행되었으며 이에 감사드립니다.

Funding: None

Conflict of interest: None

\section{REFERENCES}

1. Church TS, Tudor-Locke C, Katzmarzyk PT, Earnest CP. Trends over 5 decades in U.S. occupation-related physical activity and their associations with obesity. PLoS ONE. 2011;6(5):e19657.

2. Park YR, Kang JH, Park HA, Kim KW, Seo JS, Park NY. Comparison of obesity and overweight prevalence among korean adults according to community health survey and Korea National Health and Nutrition Examination Survey. Korean J Obes. 2014;23(1):64-68.

3. Oh SW. Obesity and metabolic syndrome in Korea. Diabetes Metab J. 2011;35(6): 561-566.

4. Gawron-S, Chrzczanowicz J, Kostka J, Nowak D, Drygas W, Jegier A, et al. Cardiovascular risk factors and total serum antioxidant capacity in healthy men and in men with coronary heart disease. Biomed Res Int. 2014;2014:216964.

5. Hao Y, Ma X, Luo Y, Shen Y, Dou Y, Pan X, et al. Serum adipocyte fatty acid binding protein levels are positively associated with subclinical atherosclerosis in Chinese pre- and postmenopausal women with normal glucose tolerance. J Clin Endocrinol Metab. 2014;99(11):4321-4327.

6. Haupt TH, Kallemose T, Ladelund S, Rasmussen LJ, Thorball $\mathrm{CW}$, Andersen O, et al. Risk factors associated with serum levels of the inflammatory biomarker soluble urokinase plasminogen activator receptor in a general population. Biomark Insights. 2014;9:91-100.

7. Hong NS, Kim JG, Lee YM, Kim HW, Kam S, Kim KY, et al. Different associations between obesity and impaired fasting glucose depending on serum gamma- glutamyltransferase levels within normal range: a cross-sectional study. BMC Endocr Disord. 2014;14:57. 
8. Kemp MW, Kallapur SG, Jobe AH, Newnham JP. Obesity and the developmental origins of health and disease. J Paediatr Child Health. 2012;48(2):86-90.

9. Na YM, Park HA, Kang JH, Cho YG, Kim KW, Hur YI, et al. Obesity related disease and disability. Korean J Fam Med. 2011;32(7):412-422.

10. Kang JH, Jeong BG, Cho YG, Song HR, Kim KA. Socioeconomic costs of overweight and obesity in Korean adults. J Korean Med Sci. 2011;26(12):1533-1540.

11. Namboodiri KK. The collaborative lipid research clinics family study: biological and cultural determinants of familial resemblance for plasma lipids and lipoproteins. Genet Epidemiol. 1985;2(3):227-254.

12. Gidding SS, Stone NJ, Bookstein LC, Laskarzewski PM, Stein EA. Month-to-month variability of lipids lipoproteins and apolipoproteins and the impact of acute infection in adolescents. $J$ Pediatr. 1998;133(2):242-246.

13. Stein EA, Sniderman A, Laskarzewski P. Assessment of reaching goal in patients with combined hyperlipidemia: low-density lipoprotein cholesterol, non-high-density lipoprotein cholesterol, or apolipoprotein B. Am J Cardiol. 2005;96(9A):36K-43K.

14. Ahn YH, Yoon KE, Park CO, Kim TJ. A correlative study on serum lipids levels in persons with hypertension and/or overweight among Koreans. Korean J Clin Lab Sci. 1988;20(1): 94-101.

15. Ahaneku JE, Agbedana OE, Taylor OG. Relationship between body mass index (BMI) and changes in plasma total and HDL-cholesterol levels during treatment of hypertension in African patients. Acta Med Okayama. 1995;49(5):267-270.

16. Jones CA, Ross L, Surani N, Dharamshi N, Karmali K. Framingham ten-year general cardiovascular disease risk: agreement between BMI-based and cholesterol-based estimates in a South Asian convenience sample. PLoS One. 2015; 10(3): $\mathrm{e} 0119183$.

17. Kim H. Correlations between waist-hip ratio, body fat, BMI (body mass index), relative body weight and serum lipids by men and women. JKAN. 1999;29(3): 596-604.

18. Ogawa H, Fujitani K, Tsujinaka T, Imanishi K, Shirakata H, Kantani A, et al. InBody 720 as a new method of evaluating visceral obesity. Hepatogastroenterology. 2011;58(105):42-44.

19. Wellens RI, Roche AF, Khamis HJ, Jackson AS, Pollock ML, Siervogel RM. Relationships between the body mass index and body composition. Obes Res. 1996; 4(1):35-44.

20. Deurenberg P, Yap M, van Staveren WA. Body mass index and percent body fat: a meta analysis among different ethnic groups. Int J Obes. 1998;22(12):1164-1171.

21. Reilly MP, Rader DJ. The metabolic syndrome: more than the sum of its parts. Circulation. 2003;108(13):1546-1551.

22. Zalesin KC, Franklin BA, Miller WM, Peterson ED, McCullough PA. Impact of obesity on cardiovascular disease. Med Clin North Am. 2011;95(5):919-937.

23. Chu MA. Obesity and metabolic syndrome among children and adolescents in Korea. J Korean Med Assoc. 2010;53(2):142-152.

24. Mueller WH, Wear ML, Hanis CL, Emerson JB, Barton SA, Hewett-Emmett D, et al. Which measure of body fat distribution is best for epidemiologic research?. Am J Epidemiol. 1991;133(9):858-869.

25. Jang HS. A study on total body fat by means of skinfold thickness, energy intake, and daily energy expenditure of college students. Korean Soc Food Nutr. 1994;23(2):219-224.

26. Jeong HC, JangKJ. College students' attitude toward body weight control, health- related lifestyle and dietary behavior by self-perception on body image and obesity index. J Korean Soc Food Nutr. 2005;34(10):1559-1565.

27. Kong M, Yun J. A study on the influence of college life stresses on the mental health of college students. Journal of Rehabilitation Psychology. 2012;19(1):1-22.

28. Ledwoż, Michalak J, Stępień A, Kạdzio ł ka A. The relationship between plasma triglycerides, cholesterol, total lipids and lipid peroxidation products during human atherosclerosis. Clinica Chimica Acta. 1986;155(3):275-283.

29. Lee GJ, Kim SK, Lee CK, Lee SG, Oh JH, Cho KJ. Prevalence rate of obesity and serum lipid test results of Korean adult employees in recent medical check-up data. Korean J Clin Lab Sci. 2008;40(2):55-61.

30. Lubkowska A, Radecka A, Bryczkowska I, Rotter I, Laszczyńska M, Dudzińska W. Serum adiponectin and leptin concentrations in relation to body fat distribution, hematological indices and lipid profile in humans. Int J Environ Res Public Health. 2015; 12(9):11528-11548.

31. Shin HG, Na YA. Concentration of serum cholesterol and triglyceride in health checkup groups at life transition periods (40 years old and 66 years old) in partial area of Korea. Korean J Clin Lab Sci. 2010;42(2):92-96. 